数を、ブレース種別ごと、用途種別ごとにわかるように示したものが図 1である。なお、一棟に複数の種類のブレースが用いられている場合 には、両方の種別でカウントしている。

最も多く用いられていたのは山形鋼であり、ターンバックルブレース、 円形鋼管と続く。「屋内運動場・格技場」に分類される建物では、桁行 方向に山形鋼ブレースが用いられ、梁間方向はラーメン構造としてい るものが典型的であった。一方、「屋内運動場・格技場」以外の建物 については、ターンバックルブレースが用いられるケースが相対的に 多かった。

\section{3 調査建物の建設年代とブレース種別}

建設年代については既報 ${ }^{1)}$ と同様、対象とする建物を、(a) 1981 年 以前建設で未診断あるいは未補強の建物、(b) 1981 年以前建設で 補強済あるいは診断の結果補強不要とされた建物、および (c) 1982 年以降建設の建物、の 3 種類に分類した。この年代分類ごと、各ブ レース種別ごとの棟数を示したものが図 2 である。図2には塗り分けに より被害の状況も示してあるが、それについては 3.2 節で説明する。

今回調査した建物で、(a)未診断あるいは未補強の建物において は、ターンバックルを用いたものが最も多く、これに山形鋼が続いてい る。一方、(b)補強済み・補強不要、あるいは(c)1982 年以降建設の建 物においては、山形鋼を用いた建物が大部分を占めている。

\section{3. 鉛直ブレース被害の被害レベル}

本章では、ブレース種別ごと、建物ごとについて、鉛直ブレース被害 程度の全体概要を述べる。まず 3.1 節では被害レベルの定義を示し、 これにもとづいて分類整理した結果を 3.2 節で報告する。

\section{1 被害レベルの定義}

鉄骨造建築物の被災度区分判定調査表 ${ }^{2}$ から、鉛直ブレースの被 災度判定区分に関する部分を表 1 に示す。本報でも基本的にこれに 基づいて分類を行うが、より損傷の程度を適切に評価することを目的 として、同等と考えられる被害を付け加えた部分がある。追加した部 分を含め、以下に分類基準を示す。

\section{被災度区分 Os}

被災度区分 $0 \mathrm{~s}$ は、鉛直ブレースおよび接合部分について、座屈、 降伏、ボル卜滑り、破断等の被害がまったく観察されなかったものとし た。ただし、ターンバックルにおいては、たわみが観察されていたとし ても、降伏が目視で確認できなかった場合には「無被害」と判断し、0s に分類した。

\section{被災度区分Is}

座屈によるわずかなたわみが観察されるが、明確に降伏現象が目 視により観察されないものを被災度区分 Is に分類した。Isに分類さ れた例を図3(a)に示す。表 1 に示したように、被災度区分のIsに該 当する被害は「圧縮筋かい」のわずかな座屈変形と定義されている。 しかし本報ではIIs に該当するような明らかな軸降伏は観察されな いものの、局所的な塑性化を伴うわずかなたわみが観察された場合 には、そのブレースが損傷を受けていることから、被災度区分 Is とし て分類した。

\section{被災度区分 IIs}

被災度区分 IIs は、「ボルト滑り」あるいは「降伏」が観察されたも のとした。ここで「ボルト滑り」とは、ボルトの周辺や接合板の境界の 塗料の剥れ等により、明らかにボルト接合部が滑ったことが観察でき

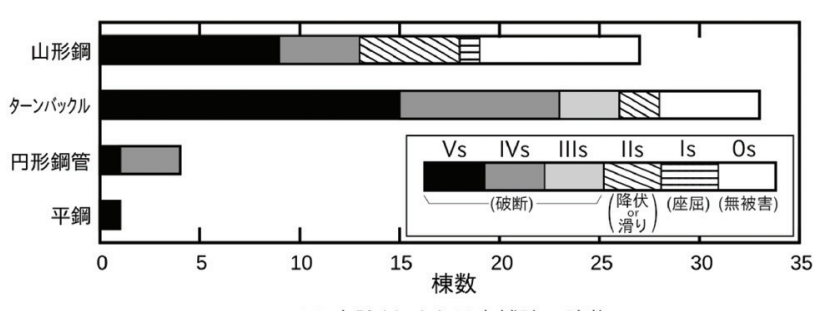

(a) 未診断、または未補強の建物

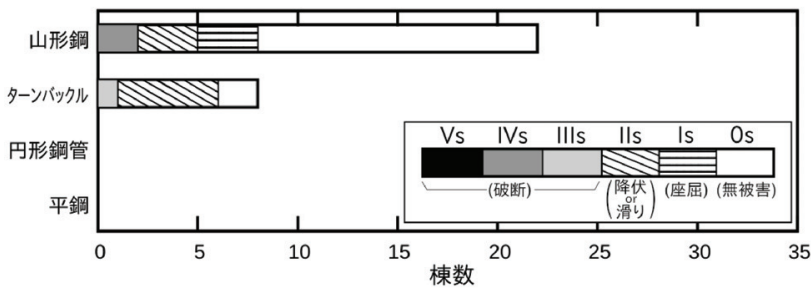

(b) 補強済み、または補強不要の建物

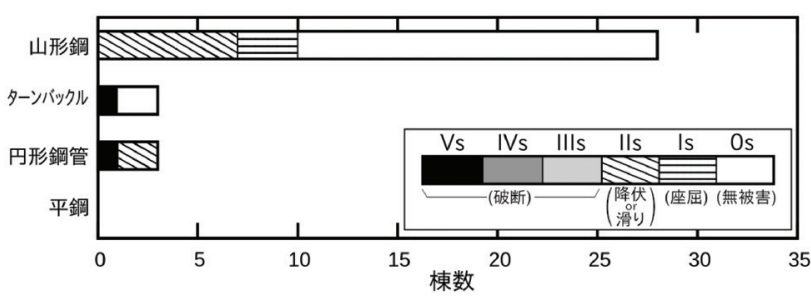

(c) 1982 年以降建設の建物

図 2 ブレース種別ごと棟数および被災度区分

表 1 被災度区分 $^{2}$

\begin{tabular}{|c|c|}
\hline 筋かい構造の被災度区分 & 筋かい構造の被害 \\
\hline $0 \mathrm{~s}$ & (以下に該当無し) \\
\hline Is & 圧縮筋かいのわずかな座屈変形 \\
\hline IIs & 高力ボルトの滑り、引張筋かいの降伏 \\
\hline IIIs & 筋かい破断 20\%以下 \\
\hline IVs & 筋かい破断 20\%〜50\% \\
\hline Vs & 筋かい破断 50\%超 \\
\hline VIs & 倒壊 \\
\hline
\end{tabular}

るもの、およびボルトが明らかに緩んでいるものと定義した。この例を 図 3(b) に示す。

また「降伏」とは、大きな残留変形や塗料の剥れなどにより、目視で 降伏が観察されたものと定義した。この例を図 3(c)に示す。表 1 の定 義においては、「引張筋かいの降伏」と限定されているが、本報では ブレース本体やターンバックル接合部の羽子板、ガセットプレートなど の部分が座屈により曲げ降伏したものについても「降伏」であると判 断し、IIs に分類している。他の例としては、枠式ターンバックル胴の 伸び変形や有効断面部分の降伏が代表的なものである。

被災度区分 IIIs Vs

完全に破断しているもの、あるいは断面に絞りやき裂が観察され、 耐力が低下していると考えられるものは「破断」と判断した上で、表 1 に示された破断ブレース数の割合に基づき、IIIs〜Vs に区分した。 「破断」が観察された箇所の具体例を図3(d)に示す。ボルト破断、ボ ルト接合部破断(有効断面破断、縁端部破壊)、ターンバックル破断、 ガセット溶接部破断(柱との接合部および鋼管との接合部)、ねじ部 破断(ターンバックルや鋼管のねじ部)などがある。なお、軽量形鋼によ る構造で、ブレース端部のフック状になっている接合部が外れて脱落 した被害についても、ブレース耐力が完全に失なわれているという点 で「破断」に分類した。 


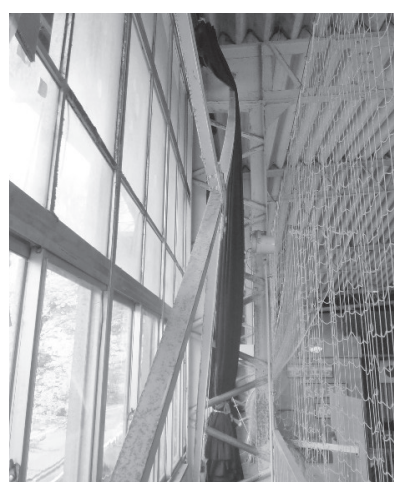

(a)座屈(被災度区分 Is)

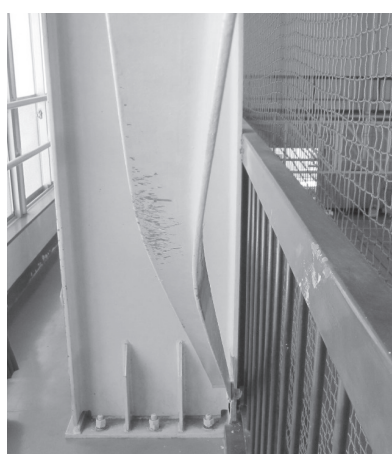

(c)降伏(被災度区分 IIs)

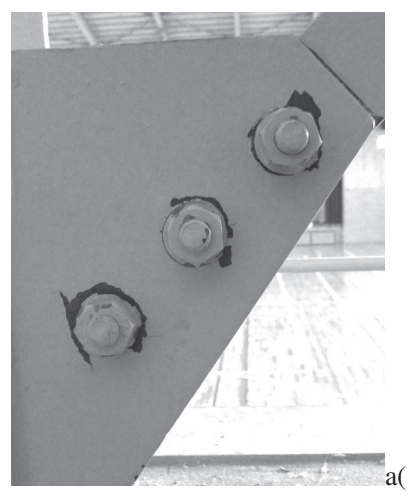

b)ボルト滑り(被災度区分 IIs)

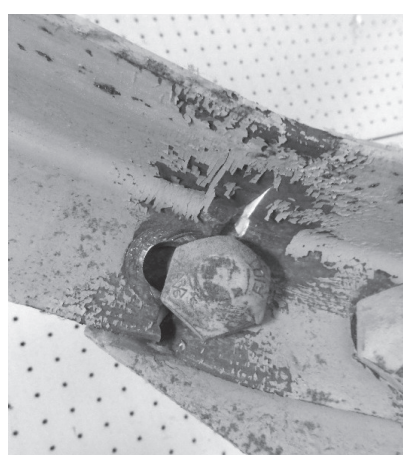

(d)破断(被災度区分 IIIs～Vs)
図 3 被害の分類例

\section{2 ブレース種別ごとの各被害レベル建物数およびその推移}

前出図2には、各ブレース種別ごとの棟数に加え、色分けにより被 災度区分をあわせて示している。各色分けは、棒グラフの根元から、 $\lceil\mathrm{Vs}\lrcorner \sim\lceil 0 \mathrm{~s}\lrcorner$ としている。

図2(a)に示した未診断あるいは未補強の建物については、調査数 全体に比して破断(IIIs〜Vs)の数が多い。特にターンバックルブレー スの破断数は全ブレース種別の中で最も多く、調査した建物の 7 割 以上で破断が観察されている。円形鋼管および平鋼ブレースについ ては調査数が少ないが、用いられていた全建物で破断している。一方、 図2(b)および(c)は、補強済・補強不要、および 1982 年以降建設の建 物の被害を示している。図2(a)と比較すると、破断被害が著しく減少 するとともに無被害の事例が増加しており、耐震補強および新耐震設 計法によって、一定の耐震性能が確保されていることがわかる。

\section{4. 鉛直ブレースの被害事例}

鉛直ブレ一スの被害事例は、ブレース種別ごと特有のものもあるが ブレース種別にかかわらない共通のものも多い。そこで本節でまずブ レース種別ごとの被害箇所を概観し、次節でそれぞれの被害事例に ついて説明を行うこととする。

\section{1 ブレース種別ごとの被害箇所}

観察された被害箇所をブレース種別ごとにまとめて示したものが図 4である。今回観察された被害のうち、破断に至った被害はすべて接 合部付近で生じたものである。全てのブレース種別に共通する被害 としては、端部のボルト接合部付近における有効断面破断・ボルトせ ん断破壊、ガセットプレート溶接部破断等が挙げられる。

また、破断に至らない被害としては、引張力により伸び変形が生じ たのち圧縮力を受けたことによるたわみや曲げ座屈による降伏が多く
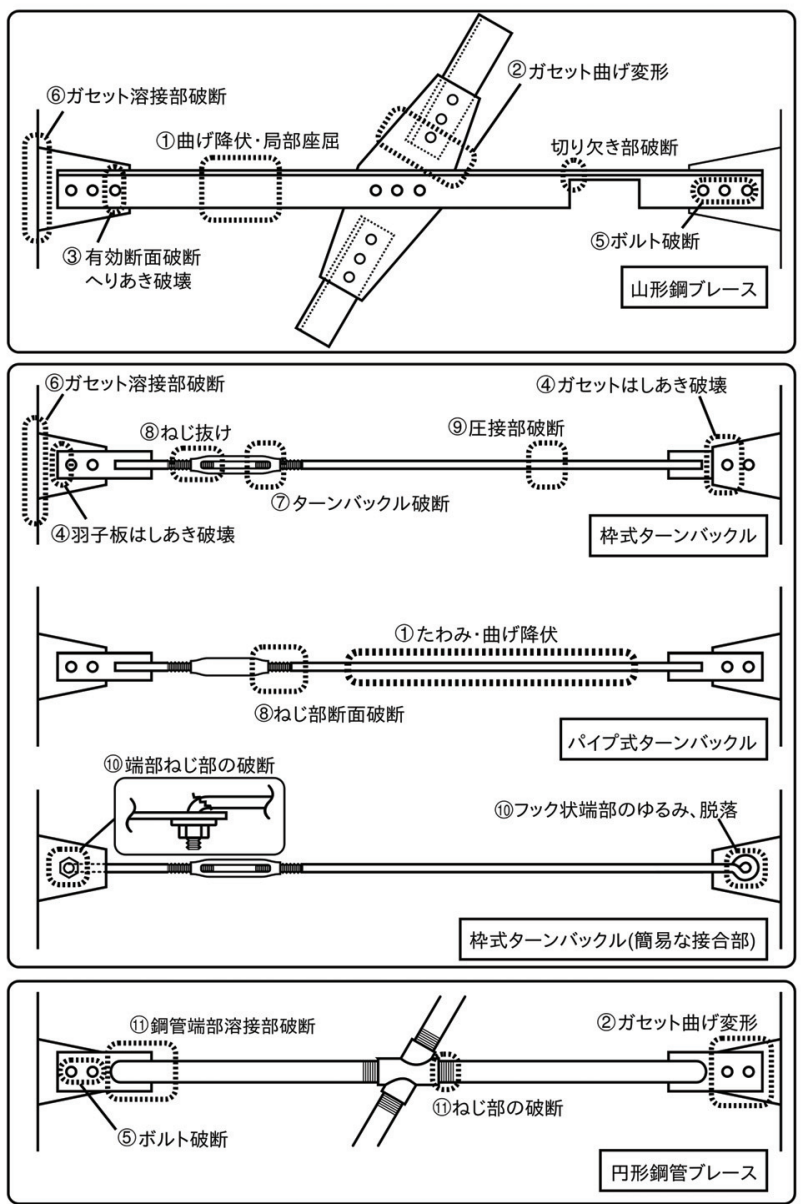

図 4 ブレース種別ごと被害箇所

観察された。特に円形鋼管や山形鋼ブレースでは、ブレース本体の曲 げ剛性が比較的高いため、座屈による曲げ変形がガセットプレート部 分に集中している例が観察される。

これらの被害箇所および形態はいずれも過去の地震被害例光ば3)4) 等 で観察されたものであり、特に新しい被害形態は見られなかった。

なお、ターンバックルブレースにおいては、枠式ターンバックルの胴 およびねじ部の引張破断が 8 棟で観察された。このうち 7 棟は 1981 年以前の未補強建物であった。建築用ターンバックルの JIS 規格に、 ねじ製法を転造法に限定したり、胴の品質規定の強化するなどの変 形能力確保の規定が追加されたのは 1982 年であり ${ }^{5)}$ 、これが指定 建築材料となったのは 2000 年のことであるから ${ }^{1)}$ 、この 7 棟の被害 は古い規格のターンバックル、または建築用 JIS 規格材でないターン バックルによるものである。残りの 1 棟は図2(c)に現われている 1982 年建設の建物であるが、これについても古い規格のもの、または JIS 規格材でないものの被害であると考えられる。

\section{2 被害事例}

\section{(1たわみ、座屈およびこれに伴う曲げ変形}

すでに図3(a)および (c)に示したように、山形鋼ブレースやターン バックルブレースおよび平鋼ブレースは通常、圧縮力への抵抗を期待 せずに設計されるため、断面が小さく、圧縮力を受けると即座に座屈 を生じる。今回の被害調査においても、これらのブレースが曲がってい るものが多数観察された。図5(a)は、より変形が進んで、局部座屈を 生じたもの、図5(b)はターンバックルブレースのたわみの例である。 
このような変形が生じた際の伸び変形量がどの程度であるかを考 えてみる。図6には、参考文献 6) に従って計算した、伸びと中央部た わみの関係を示す。横軸が塑性率あるいは伸び、縦軸が中央部のた わみを表す。右軸および上軸には、ブレース長さ $L=5000 \mathrm{~mm}$ 、降伏 伸び変形 $\delta_{y}=10 \mathrm{~mm}$ の場合を例として具体的な変形量を示している。 この例からわかるように、中央部のたわみは $100 \mathrm{~mm}$ (ブレース全長の $2 \%) に$ 達する大きなものであったとしても、引張塑性変形量は $5 \mathrm{~mm}$ (降伏変形量の半分)程度という小さなものである。今回の調査 でも、100 200mm 程度のたわみは多く観察されているが、それでも 塑性率では 2〜3 程度であり、伸びとしては大きなものではないと言 える。

\section{(2)ガセットプレートの曲げ変形}

山形鋼ブレースや円形鋼管ブレースが圧縮力を受けると、ブレース 本体にはある程度の曲げ剛性がある一方、ガセットプレートは曲げ剛 性が小さいため、座屈による曲げ変形がガセットプレートに集中する ことがある。この例を図7に示す。この例では、ガセットプレートの塗装 が折れ曲がりに沿って剥離しており、この部分に大きな塑性変形が加 えられたことがわかる。

\section{(3)山形鋼ブレースの破断}

引張力による山形鋼ブレース本体の破断被害は、全てボルト孔周 辺の有効断面破断や縁端部破壊によるものである。これらの被害事 例のなかには、山形鋼ブレースのたわみが観察されており、山形鋼ブ レースが多少伸びた後に接合部が破断したことが推定されるものも ある。しかし、塗装の剥れ等の降伏の痕跡は破断箇所や折れ曲がり 箇所周辺に限定されており、接合部が破断する以前に、山形鋼ブレー ス本体が全長にわたって十分な塑性変形をしたと認められる例は観 察されなかった。図 2 に示したように、山形鋼ブレ一スで破断を生じた ものは、すべて建設年が 1981 年以前であり、保有耐力接合にはなっ ていない。

前出図 3(d)および図8(a) は有効断面破断の例である。図8(a)に示 した山形鋼ブレース端部被害を見ると、塗装の剥離はボル卜孔周辺に 集中しており、塑性変形がこの部分に集中したことを示している。また、 第二ボルト孔周辺部も若干のくびれが観察される。設計図書には、鋼 材の材質は SS41 相当品、特記なき高力ボルトは F10T との記述が 見られ、これに基づいて計算すると、このブレース軸部の降伏耐力は およそ $180 \mathrm{kN}$ 、山形鋼の有効断面破断で決まる接合部の最大耐力 ${ }^{7)}$ はおよそ $140 \mathrm{kN}$ と算出される。このように、ブレース本体の降伏耐力 の 8 割程度しかなく、ブレース本体が塑性変形する以前に接合部が 破断に至ったことが説明される。

一方、図8(b) は片側のへりあき部分が破断してボルトが抜けだした ものである。このブレースは山形鋼 L-50x50x6であるのに対し、ボル トが M20 であるため、最小縁端距離 ${ }^{8)}$ である $26 \mathrm{~mm}$ が確保できてお らず、この部分が早期に破壊したものである。

図8(c) は第一ボルト孔で有効断面破断したものであるが、破断面 をあわせてみると、 $30 \mathrm{~mm}$ 弱ほど伸びていることがわかる。このブレー スの全長は $4350 \mathrm{~mm}$ であったことを考えれば、全長に対しておよそ $0.7 \%$ 程度の伸び変形の後に破断したことになり、破断までの伸び量 は小さい。

\section{(4)ガセットプレートおよび羽子板の破壊}

図9(a)は鉛直ブレ一スを止めていたボルトが板から抜けだした、は

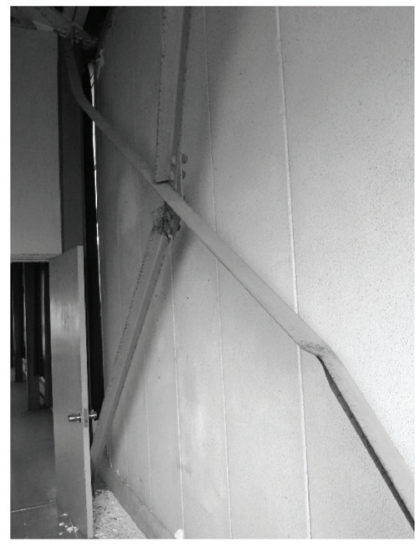

(a) 局部座屈

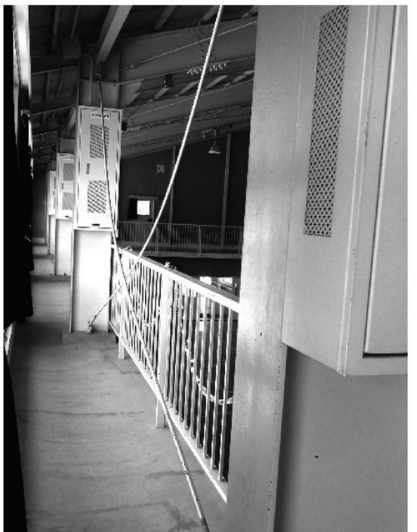

(b) ターンバックルブレースのたわみ

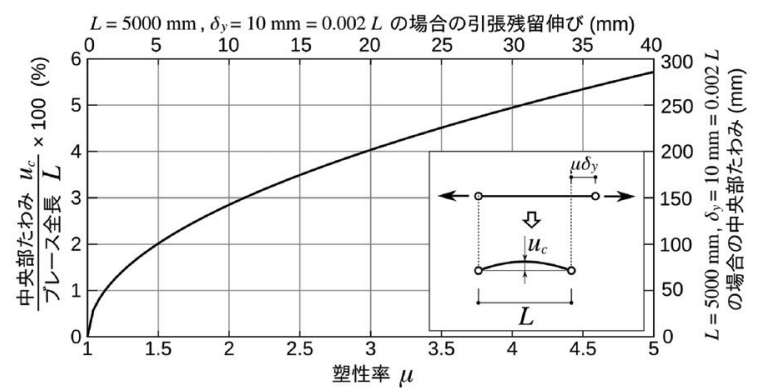

図 6 平均伸び変形量と中央部たわみの関係 ${ }^{4}$ )に基らき作成

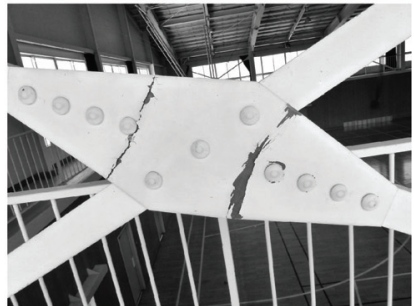

(a) ガセットプレートの折れ曲がに

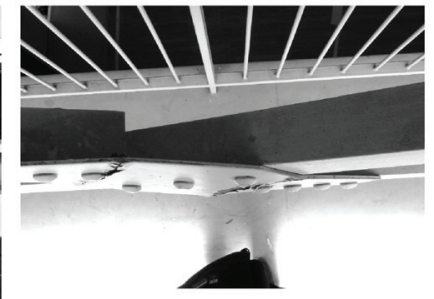

(b) (a) を上からみたところ
図 7 ガセットプレートの曲げ変形

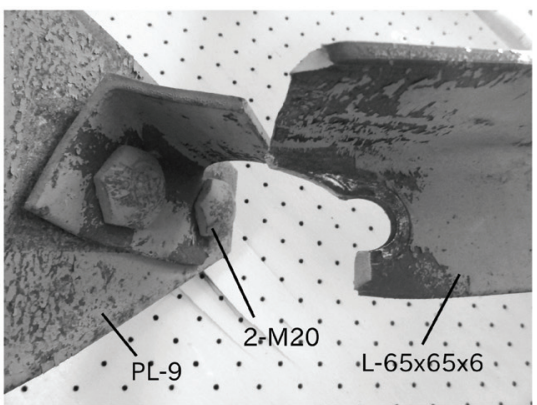

(a) 有効断面破断

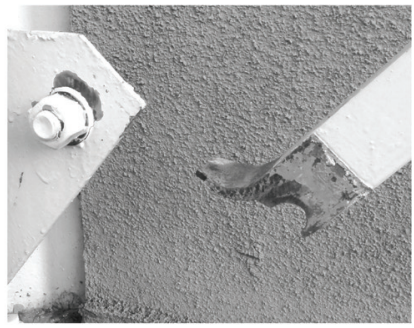

(b) へりあき不足による破断

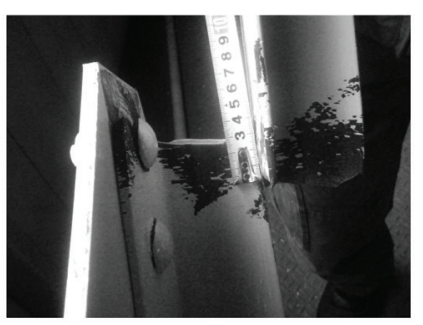

(c)破断伸び量 
しあき破壊の例である。この箇所は、当初の設計ではブレースが付く ところではなかったが、利便のために隣接構面に設置予定だった鉛直 ブレースを移動してこの箇所に設置したものと思われる。既存のガ セットプレートを利用してボルト孔を設けたために、十分なはしあきが 取れずに、破壊したものと考えられる。

また、図9(b) はターンバックルブレースの羽子板のはしあき破断の 例である。ガセットプレートや羽子板が小さく、はしあきも小さかったた めに軸部降伏に先行して破断したものと思われる。

\section{(5)接合部ボルト破断}

山形鋼ブレース、ターンバックルブレースおよび円形鋼管ブレース について、端部ボルト接合部のボルトが破断しているものが観察され た。一例として、ターンバックルブレース端部の破壊例を図 10に示す。 これは前述図8(a) の被害建物に設置されていたターンバックルブ レース端部の被害である。ブレース軸部は $\phi 22$ の丸鋼、端部接合部 は 1-M22, PL-9 となっている。接合部ボルトが設計図書どおり F10T だったとすると、 1 面せん断の最大耐力は $228 \mathrm{kN}$ である ${ }^{9} 。 一$ 方、丸 鋼軸部の最大耐力は $152 \mathrm{kN}$ と計算される。このように高力ボルトで あれば、接合部ボルトの最大耐力は軸部最大耐力よりも 5 割程度大 きく、ボルト破断は起こらないが、中ボルトが使われていたため、ボル トが破断したものである。

\section{(6)ガセット接合部破断}

図11(a)は H 形鋼柱のウェブに隅肉溶接されていた、山形鋼ブレ一 ス端部のガセットプレートが抜けだして破壊した例である。眓11(b)は 同じ箇所を柱 $\mathrm{H}$ 形鋼ウェブの反対側から撮影したものであるが、ガ セットプレート側からの亀裂が柱 $\mathrm{H}$ 形鋼ウェブを貫通して手前に現れ ている。

設計図面および現場での観察によれば、少なく見積もっても、有効 溶接長さは片側でおよそ $200 \mathrm{~mm}$ 程度である。降伏応力度を 235 $\mathrm{N} / \mathrm{mm}^{2}$ 、隅肉サイズ $6 \mathrm{~mm}$ とすると隅肉溶接部の降伏耐力はおよそ $220 \mathrm{kN}$ 程度と推定される。一方、山形鋼ブレース (L-75x75x6(SS 400)）端部の有効断面破断で決まる最大耐力 71 は $205 \mathrm{kN}$ 程度であ り、この溶接部分の耐力はある程度確保されているものと推定される。 したがって、この破壊は隅肉溶接が不適切だったのではなく、柱ウェ ブに直接溶接されるディテールだったために、ウェブが局所的に著し い面外曲げ変形を受けてこの部分が破断したものと考えられる。

\section{(7)ターンバックルの降伏·破断}

調査した建物に用いられていたターンバックルは、枠式とパイプ式 の 2 種類であったが、ターンバックル胴が破断しているものはすべて 枠式のものである。図12(a)および(b)は、枠式ターンバックル本体が 破断している例を示す。図12(a)は、朹の一方が破断したものであるが、 丸鋼ブレース軸部の塗装は健全であり、破断箇所以外には降伏の形 跡は観察されない。また図12(b) は完全に破断した例であるが、枠の 端部とねじ部の塗装がはがれており、この部分に塑性変形が集中し た結果、最終的に枠が破断していることがわかる。前述したように、い ずれも古い規格のターンバックルであり、十分な耐力と変形能力を有 しなかったため破断に至ったものである。

\section{(8)ターンバックルねじ部の破断}

図13はねじ部破断の状況を示す。(a)はパイプ式ターンバックルのね じ部での破断である。前出図12(b) でも見たように、ターンバックルね じ部ではかなりの伸び変形が生じ、限界に達するとここで破断する。

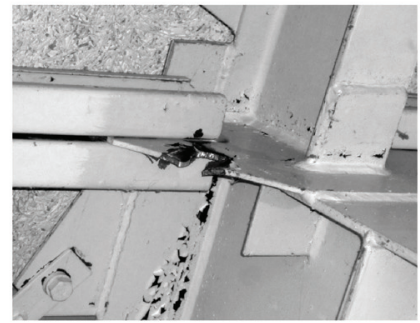

(a) ガセットプレートの破壊

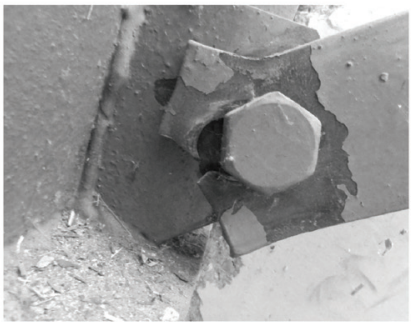

(b)羽子板の破壊
図 9 ガセットプレートのはしあき破壊

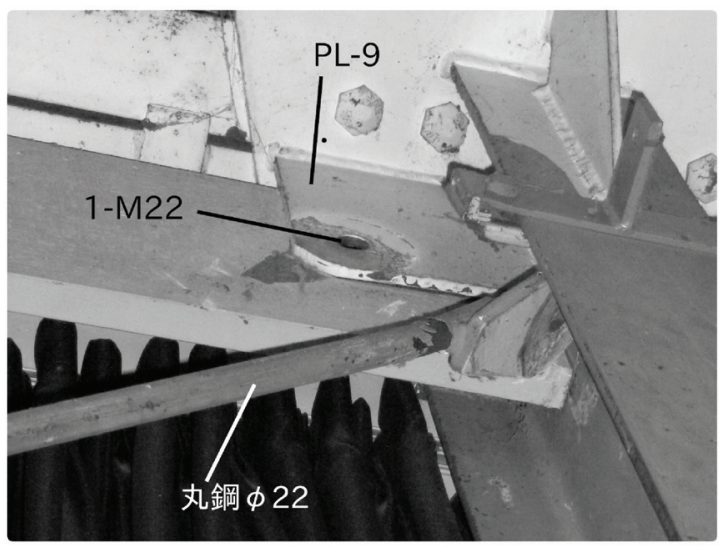

図 10 ターンバックルブレース端部のボルト破断

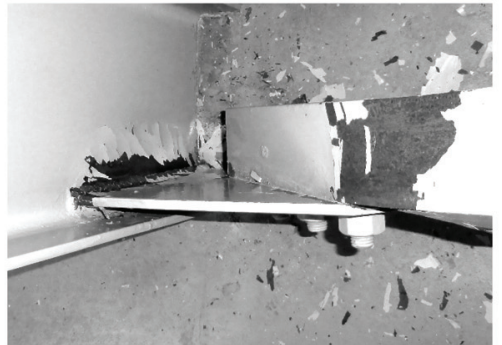

(a) 柱ウェブからの抜け出し

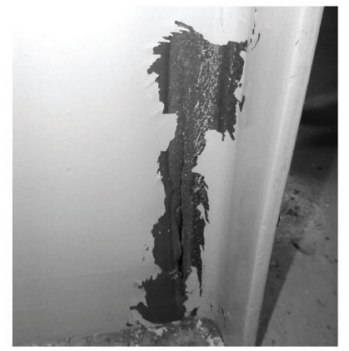

(b) (a)のウェブ反対側
図 11 ガセッ接合部破断

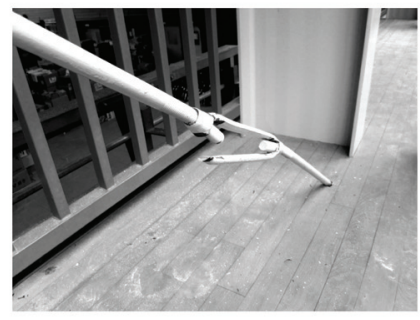

(a)

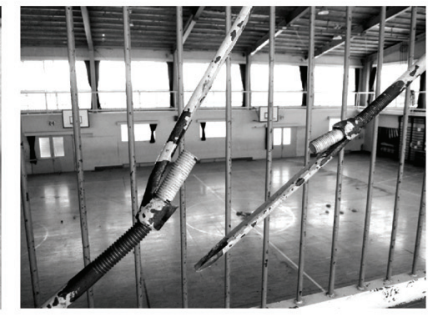

(b)
図 12 ターンバックルの破断

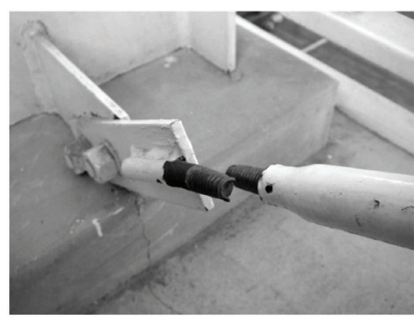

(a) ねじ部破断

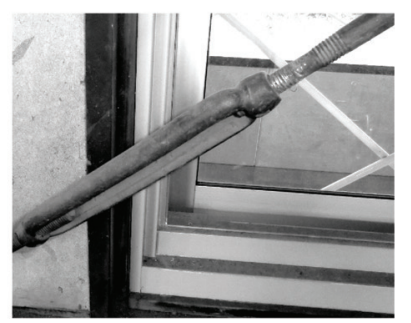

(b)ねじ抜け
図 13 ターンバックルねじ部破断 
また、図13(b)は、ターンバックル上側のねじ部が大きく伸びてしまい、 ターンバックルから抜け出してしまったものである。破断したものはい ずれも切削ねじであり、ペイントの剥離がねじ部のみに集中している ことから、ねじ部に塑性変形が集中していることがわかる。

\section{(9)ターンバックル丸鋼圧接部の破断}

図14(a), (b) は、ターンバックルブレースの丸鋼圧接部の破断の例 である。この部分は径の異なる丸鋼を圧接したものであるが、いずれ も十分な伸び変形をせずに破断している。破断面はほぼ平らで一部 錆びている箇所があることから、断面の周囲のみが圧接されていて十 分な伸び変形をせずに破断してしまった可能性がある。

(10)ターンバックルブレース端部接合部の破断および外れ

簡易な鉄骨構造物では、丸鋼の端部を曲げて、ボルトの頭や孔に 引つ掛けるようにして接合されたブレースが見られ、これらにも被害が 観察された。図15(a)は、ターンバックルブレースの端部をボルトの頭 に引つ掛ける形の接合部であるが、引張力により曲げた部分が開きか けている。図15(b)は、ターンバックルブレース端部を曲げてねじを切り、 孔を通して反対側でボルトで止めているディテールであるが、ブレー スを曲げた部分で破断している例等が観察された。

\section{(11)円形鋼管端部接合部の破断}

図16(a)は、円形鋼管ブレースの端部接合部が割り込んで溶接して あるところで破断している例である。破断の要因としては、溶接部の 設計・施工に問題があった可能性のほか、接合しているガセットプ レートも大きく面外に曲がっており、ブレースが圧縮力を受けた際に座 屈によりガセットプレートに過度な曲げ変形が生じ、これが破壊を導い た可能性も考えられる。また図16(b) は、鋼管に直接ねじを設けた接 合部において、ねじ部が破断した例である。ねじ部の欠損断面積のた め、この部分から早期に破断したと考えられる。

\section{5. まとめ}

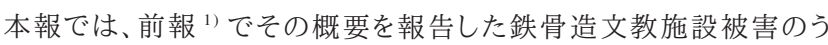
ち、鉛直ブレース被害について詳細に報告した。調査対象とした建物 のうち、1981 年以前建設でかつ未補強の建物において鉛直ブレース 破断の被害が多い一方、補強済み・補強不要、または 1982 年以降建 設の建物では破断被害が少なくなっていることがわかった。

個別の破断被害としては、有効断面破断、縁端部破壊、站じ部破断、 溶接部破断など、様々な様態が観察されたが、いずれにも共通してい るのは、ブレース本体が十分な塑性変形能力を発揮しないまま破断し ている点である。破断までの伸び変形量は、計測できたもので 20〜 $30 \mathrm{~mm}$ 程度、ブレース全長に比して $1 \%$ 程度以下であった。他の多く のブレースについても、観察された破断後の変形状態から、破断まで の伸び変形はおよそ同程度以下であったと推測される。一方、1982 年以降建設あるいは補強済・補強不要の建物では破断の被害が少 なかったことからも、鉛直ブレースを保有耐力接合となるように設計し ブレースの伸び変形能力を向上させることが鉛直ブレース破断被害 の低減に有効である、ということが再確認された。

はしあき・へりあき不足、面外曲げ拘束のためのスチフナ欠損、中 ボルトの利用、ブレース軸部に切り欠きを設けてしまったものなど、明 らかに不適切な設計・施工による被害もあった。このような不適切な 設計・施工は最近は減少してきていると思われるが、被害の発生を防 ぐために今後も継続して注意を喚起してゆくことが重要である。

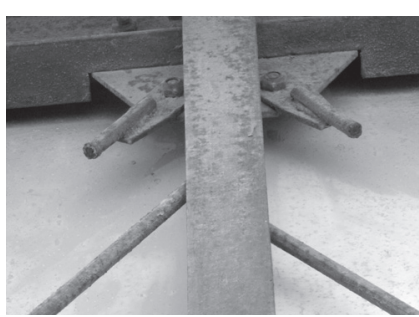

(a)

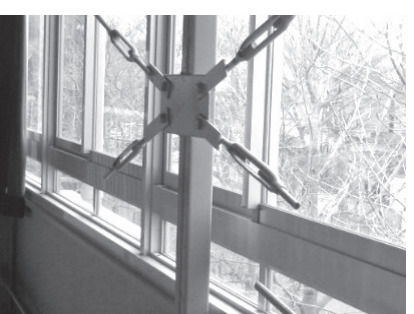

(b)

図 14 丸鋼圧接部破断

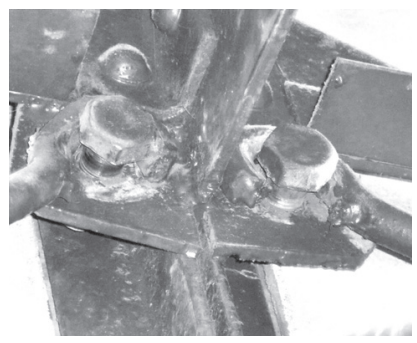

(a)

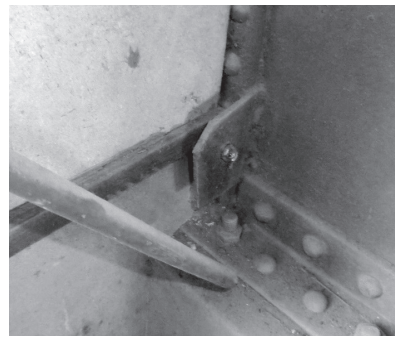

(b)
図 15 ターンバックルブレース各種端部接合部の破壊

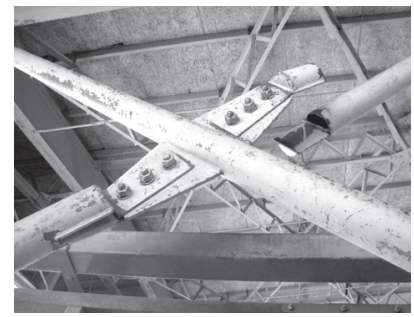

(a) 割り込み継手の破壊

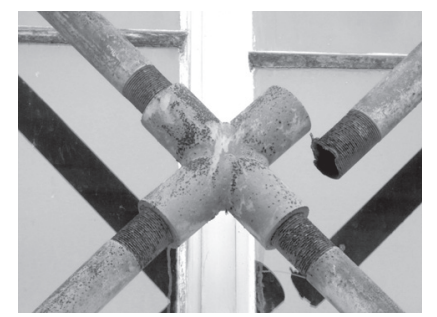

(b) ねじ込み継手の破壊
図 16 円形鋼管接合部の破壊

謝辞

本報告で取りまとめた調査にあたつては、植松 康先生(東北大学)、 五十子幸樹先生(東北大学)、ガヴァンスキ江梨先生(東北大学)、見 波進 先生(東京電機大学)、池永昌容先生(東北大学)、伊藤拓海先 生(東京理科大学)、田中剛先生(神戸大学)、浅田勇人先生(神戸大 学)をはじめ、耐震性能等小委員会委員各位のご協力を得た。また、 調査対象となった施設では、施設関係職員の方々の多大なるご協力 を得た。ここに記して謝意を表す。

\section{参考文献}

1) 山田 哲 他: 東北地方太平洋沖地震等で被災した鉄骨造文教施設の調査 -調查の概要-, 日本建築学会技術報告集,第 40 号, pp. 935-940, 2012.10

2) 日本建築防災協会:震災建築物の被災度区分判定基準および復旧技術指 針第 2 版, 2002.8

3) 日本建築学会 学校建築委員会 耐震性能小委員会: 文教施設の耐震性 能等に関する調查研究報告書, 1996.3

4) 日本建築学会 文教施設委員会 耐震性能小委員会: 文教施設の耐震性 能等に関する調查研究報告書, 2005.3

5) 日本鋼構造協会 : 建築用ターンバックル設計施工指針・同解説, JSS IV 01-2005, p.v, 2005.

6) 齊藤諭,吉敷祥一,浅田勇人,山田哲:接合部を含む引張ブレース部材の面 外変形と損傷の関係, 2011 年度日本建築学会関東支部研究報告集 I, pp. 565-568 (No.2094), 2012.3

7) 日本建築学会：鋼構造接合部設計指針, 6.1.2 節, pp. 263-264, 2012

8) 日本建築学会 : 鋼構造接合部設計指針, 2.1.2 節, p.45, 2012

9) 日本建築学会：鋼構造接合部設計指針,付 2 , p. 371, 2012 